\title{
Extent of prominence given to home science information in selected dailies
}

\author{
PRIYANKA A. KAUSADIKAR* AND UMA S. HIREMATH ${ }^{1}$ \\ Rajiv Gandhi Agricultural College, Vasantrao Naik Marathwada Krishi Vidyapeeth, \\ PARBHANI (M.S.) INDIA \\ (Email : priyankakausadikar@yahoo.com)
}

\begin{abstract}
The research investigation was carried out during the period of five months i.e. from $1^{\text {st }}$ April, 2007 to $31^{\text {st }}$ August, 2007 in Parabhani district of Maharashtra state to know the prominence given to home science information in selected dailies. On high circulation basis, two national English (Times of India and Indian Express) and two regional Marathi (Sakal and Lokmat) dailies were selected. Around half of the items appeared in seventh and later pages followed by special supplement (25.76\%) of newspaper. Majority of the home science articles were having headline width less than two columns and with one illustration. Most of them were containing black and white illustrations and in the form of pictures/photos.
\end{abstract}

KEY WoRDS : Prominence, Page number, Headline width, Illustrations, Colour, Forms

View Point Article : Kausadikar, Priyanka A. and Hiremath, Uma S. (2014). Extent of prominence given to home science information in selected dailies. Internat. J. Home. Sci. Extn. \& Comm. Mgmt., 1 (2): 134-138.

Article History : Received : 14.05.2014; Revised : 10.06.2014; Accepted : 22.06.2014 